\title{
Phase toxicity of dodecane on the microalga Dunaliella salina
}

\author{
Dorinde M. M. Kleinegris • Marjon A. van Es • \\ Marcel Janssen • Willem A. Brandenburg • \\ René H. Wijffels
}

Received: 28 May 2010 /Revised and accepted: 14 October 2010 /Published online: 6 November 2010

(C) The Author(s) 2010. This article is published with open access at Springerlink.com

\begin{abstract}
In the so-called milking process of Dunaliella salina carotenoids are extracted and simultaneously produced by the culture, whilst the biomass concentration remains constant. Different theories exist about the extraction mechanisms although none have been proven yet. In this research, direct contact between dodecane and cells during the extraction process was studied microscopically and effects of direct contact were determined during in situ extraction experiments. Our results showed that watersolvent interphase contact resulted in cell death. This cell death and consequent cell rupture resulted in the release and concomitant extraction of the carotenoids. Furthermore, it has been suggested to add a small amount of dichloromethane to the biocompatible dodecane to create an organic phase with more extraction capacity. Our results showed that the addition of dichloromethane resulted in increased cell death and consequently the extraction rate increased. The improved solubility of carotenoids in an organic phase with dichloromethane did not significantly increase the extraction rate.
\end{abstract}

Keywords $\beta$-carotene - Dichloromethane - Dodecane . Dunaliella salina $\cdot$ Extraction $\cdot$ Organic phase

D. M. M. Kleinegris $(\bowtie) \cdot$ M. A. van Es $\cdot$ M. Janssen •

R. H. Wijffels

Bioprocess Engineering,

Wageningen University,

P.O. Box 8129, 6700 EV Wageningen, The Netherlands

e-mail: dorinde.kleinegris@wur.nl

URL: www.algae.wur.nl

W. A. Brandenburg

Plant Research International BV, Agrosystems research, Wageningen University and Research Centre,

P.O. Box 16, 6700 AV Wageningen, The Netherlands

\section{Introduction}

Dunaliella salina is the main natural producer of $\beta$ carotene. This unicellular, halotolerant microalga produces this carotenoid up to $10 \%$ of its dry weight when stressed. Commercial production of $\beta$-carotene with algae is done by growing and stressing the algae in open ponds (Ben-Amotz 1995; Borowitzka 1999). During this process, the algae are first grown to obtain a high biomass. Next, the cells are stressed to produce $\beta$-carotene. Stress is implied by increasing the light intensity or allowing the water of the ponds to evaporate to increase the salt concentration. When high levels of $\beta$-carotene are reached, the biomass is harvested and further processed.

Milking the algae is a newly introduced method to continuously produce and simultaneously extract carotenoids from $D$. salina in closed reactor systems. The extraction is performed by adding a biocompatible organic solvent (dodecane) to the bioreactor. During the milking process, the production of $\beta$-carotene by the cells is prolonged while it is extracted in situ at the same time. As a result, the production step in which biomass is grown, does not need to be continuously repeated, increasing the overall volumetric productivity of carotenoids. The milking process can last for several weeks, with constant biomass levels and increasing amounts of extracted $\beta$-carotene (Hejazi et al. 2004a).

Though the process was shown to be successful, the mechanism behind it is unclear. It was hypothesized that $\beta$ carotene was extracted from the cells while the cells stayed viable and kept producing carotenoids under the stress conditions applied. It is unclear whether carotenoids are released from the cells into the water phase after which they are transferred into the dodecane phase or whether direct contact between cells and the dodecane phase is required 
and what the effect of direct contact between dodecane and cells is on the viability of the biomass. The mechanism of $\beta$-carotene transport across the cell membrane is also unknown.

In previous research, two hypotheses concerning the carotenoid extraction were proposed (Hejazi et al. 2004b). The first hypothesis suggested an active role for endocytosis and exocytosis. The other hypothesis was based on diffusion of carotenoid molecules. Neither of these was proven true or false thus far.

Therefore, a combination of microscopic extraction experiments and macroscopic experiments in small reactors was used to reveal the mechanisms behind the extraction process. In previous studies, it was shown that adding a more polar organic solvent to the biocompatible solvent improved the extraction, because of a more favorable product distribution coefficient between the water and solvent phase (Mojaat et al. 2008; Bruce and Daugulis 1991; Evans and Wang 1988). Very small amounts of these polar, normally more toxic, components should not be toxic to the cells in a two-phase system, as long as the critical aqueous concentration is not reached. This is the concentration of toxic component in the water phase corresponding to the concentration of the toxic compound in the cell membrane that is lethal to the cell (Osborne et al. 1990).

In this study, we added two different volume fractions of dichloromethane to the biocompatible dodecane to determine the effect on the extraction process. Mojaat et al. (2008) showed that the solubility of $\beta$-carotene in a solvent mixture of decane and $190 \mathrm{mM}$ dichloromethane increased approximately 1.5 times compared to pure decane. Next to that, they showed a six times improved extraction of $\beta$ carotene from $D$. salina. This improved extraction was suggested to result from both the improved solubility of $\beta$ carotene and from the permeability effect of mixed solvents on the cell membrane (Mojaat et al. 2008). In this study, we also tested whether addition of dichloromethane had a positive effect on the in situ extraction process and what was its mechanism of action.

\section{Materials and methods}

Dunaliella salina CCAP 19/18 was obtained from the Culture Collection of Algae and Protozoa, Oban, UK. Stock cultures of the algae were grown in a culture medium as described by Kleinegris et al. (2010b). The medium consisted of $1.50 \mathrm{M} \mathrm{NaCl}, 9.95 \times 10^{-4} \mathrm{M} \mathrm{Na}_{2} \mathrm{H}_{2} \mathrm{PO}_{4} \cdot 2 \mathrm{H}_{2} \mathrm{O}$, $3.78 \times 10^{-2} \mathrm{M} \mathrm{KNO}_{3}, 2.25 \times 10^{-2} \mathrm{M} \mathrm{Na}_{2} \mathrm{SO}_{4}, 1.00 \times 10^{-2} \mathrm{M}$ $\mathrm{NaHCO}_{3}, 4.87 \times 10^{-3} \mathrm{M} \mathrm{K}_{2} \mathrm{SO}_{4}, 3.68 \times 10^{-4} \mathrm{M}$ $\mathrm{MgCl}_{2} \cdot 6 \mathrm{H}_{2} \mathrm{O}, 1.89 \times 10^{-5} \mathrm{M} \mathrm{CaCl} \cdot 2 \mathrm{H}_{2} \mathrm{O}$, and $1.13 \times$ $10^{-5} \mathrm{M}$ FeEDTA. In addition, the medium contained micronutrients: $1.94 \times 10^{-5} \mathrm{M} \mathrm{Na} \mathrm{Na}_{2}$ TA $\cdot 2 \mathrm{H}_{2} \mathrm{O}, 1.89 \times$
$10^{-6} \mathrm{M} \mathrm{MnCl}_{2}, 1.48 \times 10^{-6} \mathrm{M} \mathrm{ZnSO}_{4}, 6.65 \times 10^{-7} \mathrm{M}$ $\mathrm{CuSO}_{4}, 1.10 \times 10^{-8} \mathrm{M} \mathrm{Na}_{2} \mathrm{MoO}_{4}, 9.95 \times 10^{-9} \mathrm{M} \mathrm{CoCl}_{2}$. The solution was buffered with $4.00 \times 10^{-2} \mathrm{M}$ Hepes acid and adjusted to $\mathrm{pH} 7.5$ with $3 \mathrm{M} \mathrm{NaOH}$.

The medium was sterilized at $121^{\circ} \mathrm{C}$ for $30 \mathrm{~min}$. The phosphate, magnesium, calcium, and carbonate salts were separately sterilized and added after autoclaving to avoid precipitation.

All strains were maintained as suspended culture in 250$\mathrm{mL}$ Erlenmeyer flasks containing $100 \mathrm{~mL}$ of medium. Cultures were kept in a growth cabinet at $25^{\circ} \mathrm{C}$, under continuous light with an intensity of $70 \pm 10 \mu$ mol photons $\mathrm{m}^{-2} \mathrm{~s}^{-1}$ and were continuously shaken. The headspace consisted of an air/ $\mathrm{CO}_{2}$ ratio of $95 / 5 \%$. Every 3 weeks, $10 \mathrm{~mL}$ of a culture was transferred to a new flask containing fresh medium.

Cells were grown and stressed in a batch process in a flat-panel photobioreactor. Stressed cells were used for microscopy and extraction purposes.

The bioreactor consisted of two compartments, a culture compartment and a water jacket for temperature regulation, as described in more detail by Lamers et al. (2010). The culture chamber had a depth of $3 \mathrm{~cm}$. The reactor contained 2,500 $\mathrm{mL}$ of culture medium (as described above, but without the addition of Hepes buffer). Mixing and oxygen removal was provided by gassing the cell suspension with $0.6 \mathrm{~L} \mathrm{~min}^{-1}$ of dinitrogen. The $\mathrm{pH}$ was controlled at 7.5 by automatically dosing short pulses of carbon dioxide to the cell suspension. Temperature was maintained at $30^{\circ} \mathrm{C}$. The reactor was illuminated from one side with a high-pressure sodium lamp (Philips $400 \mathrm{~W}$ Master SON-T PIA Green Power) with an average light intensity of $200 \mu \mathrm{mol}$ photons $\mathrm{m}^{-2} \mathrm{~s}^{-1}$ for the growth period. During stress, light intensity was increased to $1,665 \mu \mathrm{mol}$ photons $\mathrm{m}^{-2} \mathrm{~s}^{-1}$ moving the lamp closer to the reactor. The average light intensity was measured using a PAR $2 \pi$ quantum sensor (SA-190, Li-cor Biosciences, Lincoln, Nebraska, USA).

For each cultivation, the reactor was inoculated with a stock culture to a concentration of $7 \times 10^{5}$ cells $\mathrm{mL}^{-1}$. When a cell number of more than $1 \times 10^{6}$ cells $\mathrm{mL}^{-1}$ was reached in the reactor, stress conditions were applied. Cells were stressed for at least $24 \mathrm{~h}$ during which significant amounts of $\beta$-carotene were produced $(2.2-2.5 \% \mathrm{w} / \mathrm{w})$.

Dry weight of the cell suspension was determined at the end of the cultivation, as previously described by Kleinegris et al. (2010b). Cell number and volume were measured with a Beckman Coulter Multisizer three (Beckman Coulter Inc., USA, $100 \mu \mathrm{m}$ orifice). Diameter of the cells was calculated from their volume.

During the extraction experiments, cell numbers were also determined by counting with a Bürker-Türk counting chamber. This was done because during the extraction experiments a dodecane emulsion was formed in the mixed 
two-phase reactors. As the droplets interfered with the Multisizer measurement, it was necessary to perform cell counting by microscopy. In this manner, it was possible to distinguish between droplets and cells. For every sample, a volume of $2.56 \times 10^{-4} \mathrm{~mL}(4 \times 16$ squares $)$ was counted in duplicate. Lugol solution was added to each sample to stop cell movement.

Carotenoid levels of biomass and dodecane were determined spectrophotometrically. One-milliliter aliquots of cell suspension were centrifuged at 4,000 rpm for $10 \mathrm{~min}$ (SX 4,250 rotor, Allegra X-22R, Beckman Coulter). After centrifugation, the supernatant was discarded and $3 \mathrm{~mL}$ dodecane was added. The sample was shaken vigorously to re-suspend the pellet. Then, $9 \mathrm{~mL}$ of methanol was added to completely break up the cells and the tube was shaken vigorously again and centrifuged for $3 \mathrm{~min}$ at 4,000 rpm. The dodecane-containing lipophilic carotenoids (upper layer) were measured with a spectrophotometer (Ultrospec 2,000, Pharma Biotech) at $453 \mathrm{~nm}$ and $665 \mathrm{~nm}$ and dodecane as reference.

From a previous experiment, biomass samples were used for carotenoid determination by HPLC as described by Kleinegris et al. (2010b). These samples were used to obtain a calibration curve for the spectrophotometer for $\beta$ carotene, the main carotenoid present in stressed D. salina cells (Ben-Amotz et al. 1982), see equation.

$C_{\beta-c a r}=\left(A B S_{453}-A B S_{665} / 3.91\right) \times 3.657 \times 3 \times X\left[\mathrm{mgL}^{-1}\right]$

where: $\left(\mathrm{ABS}_{453}-\mathrm{ABS}_{665} / 3.91\right)$ is the absorbance of $\beta$ carotene corrected for chlorophyll contamination, 3.657 is the calibration factor derived from HPLC analysis of $\beta$ carotene concentration, 3 is the amount of milliliters of dodecane added for extraction, $X$ is the dilution factor to measure absorbance on spectrophotometer.

The amount of extracted $\beta$-carotene in the dodecane was measured according to the same calibration curve though without the factor 3 .

Bright field microscopy pictures were made with a CK 40 bright field microscope (Olympus), equipped with an Olympus AX 70 camera. Fluorescence microscopy pictures were made with a confocal laser scanning microscope (CLSM, Zeiss LSM 510-META 18) that consisted of an inverted microscope (Axiovert $200 \mathrm{M}$ ) equipped with differential interference contrast and a range of excitation laser lines. For the excitation, we used the Argon diode laser $(30 \mathrm{~mW})$ with $488 \mathrm{~nm}$ excitation wavelength. For the detection of emitted fluorescence, the BP505-530/LP650 filter combination was used. A Zeiss $639 \alpha$-Plan Fluar oil objective (NA 1.45) was used for all imaging experiments. The observed fluorescence was emitted in green (505$530 \mathrm{~nm}$ ) by the carotenoid-rich globules in the cell and in red $(>650 \mathrm{~nm})$ by the chlorophyll (Kleinegris et al. 2010a).
In situ extraction experiments

The extraction experiments were carried out in 1-L glass bottles, containing $500 \mathrm{~mL}$ of culture medium. The bottles (diameter $9 \mathrm{~cm}$ ) were equipped with one magnetic stirrer fixed on an axis, stirring at a rate of $100 \mathrm{rpm}$. The stirrer (diameter $6.0 \mathrm{~cm}$, width $1.0 \mathrm{~cm}$ ) was placed $0.5 \mathrm{~cm}$ from the bottom in the water phase (Fig. 1).

In the first experiment, dodecane was solely used as the organic phase. In the second experiment, a mixture of dodecane and dichloromethane was used. Dichloromethane was added in two concentrations, $1.2 \% v / v$ of the total amount of organic phase and $5.0 \% \mathrm{v} / \mathrm{v}$. This corresponds to concentrations of 190 and $781 \mathrm{mM}$ of dichloromethane in the organic phase. The total volume of organic phase in each system was $200 \mathrm{~mL}$. Four reactor flasks were used for each run, two as blank and two as sparged systems. Sparging was done by pumping organic phase from the top layer to the inlet at the bottom of the reactor. Two gearpumps (VG-015.5, Verdergear), viton tubing and stainless steel connectors were used for the pumping.

Dunaliella salina cells frequently rupture and fall apart when they die. Consequently, it is difficult to count the total amount of dead cells (both intact and lysed cells) and as a result death rate is very difficult to measure. By stopping cell growth, the remaining cells could be counted and thus cell death calculated. To ensure growth arrest, hydroxyurea (Zachleder 1994) was added to the cell suspension at the start of the extraction experiments, with a final concentration of $1.28 \mathrm{mM}$. This concentration was based on a set of experiments in which a range of concentrations $(20 \mu \mathrm{M}-$ $1.5 \mathrm{mM}$ ) of hydroxyurea was tested for effectiveness.

Furthermore, the experiments were performed in the dark in order to prevent $\beta$-carotene from being broken down.

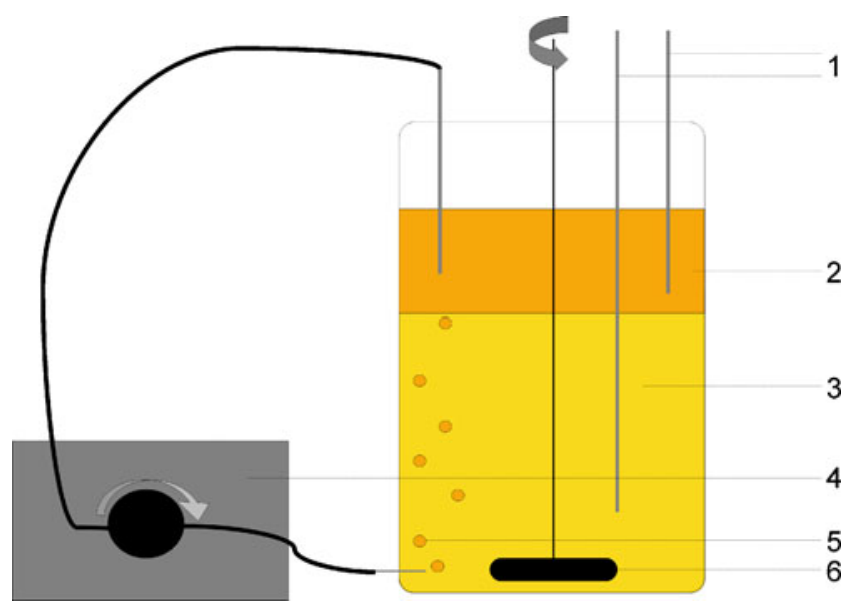

Fig. 1 Schematic overview of sparged set-up. (1) Sampling tubes for biomass phase and dodecane phase. (2) Dodecane phase. (3) Biomass phase. (4) Gear pump. (5) Sparged dodecane bubbles. (6) Magnetic stirrer 


\section{Results}

The effect of direct contact between cells and dodecane

The effect of direct contact between cells and dodecane was studied using light microscopy. Figure 2 shows cells in water droplets surrounded by dodecane. When D. salina cells were exposed to a dodecane phase, the cells actively moved away from the dodecane phase and rather stayed in the medium droplets. By adding more dodecane to the sample, medium droplets divided into smaller droplets. When the medium droplets became too small for all cells they pushed each other out and cells that came into direct contact with the dodecane fell apart, as can be seen in
Fig. 2 Light microscopy pictures of $D$. salina cells in aqueous phase surrounded by dodecane. $\mathbf{a}$ and $\mathbf{b}$ Bright field microscopy pictures. $\mathbf{c}$ and $\mathbf{d}$ CLSM pictures of surviving cells and a dead cell, respectively. e and f CLSM pictures of cell remains in the presence of dodecane. Red fluorescence is emitted by chlorophyll, green fluorescence by $\beta$-carotene
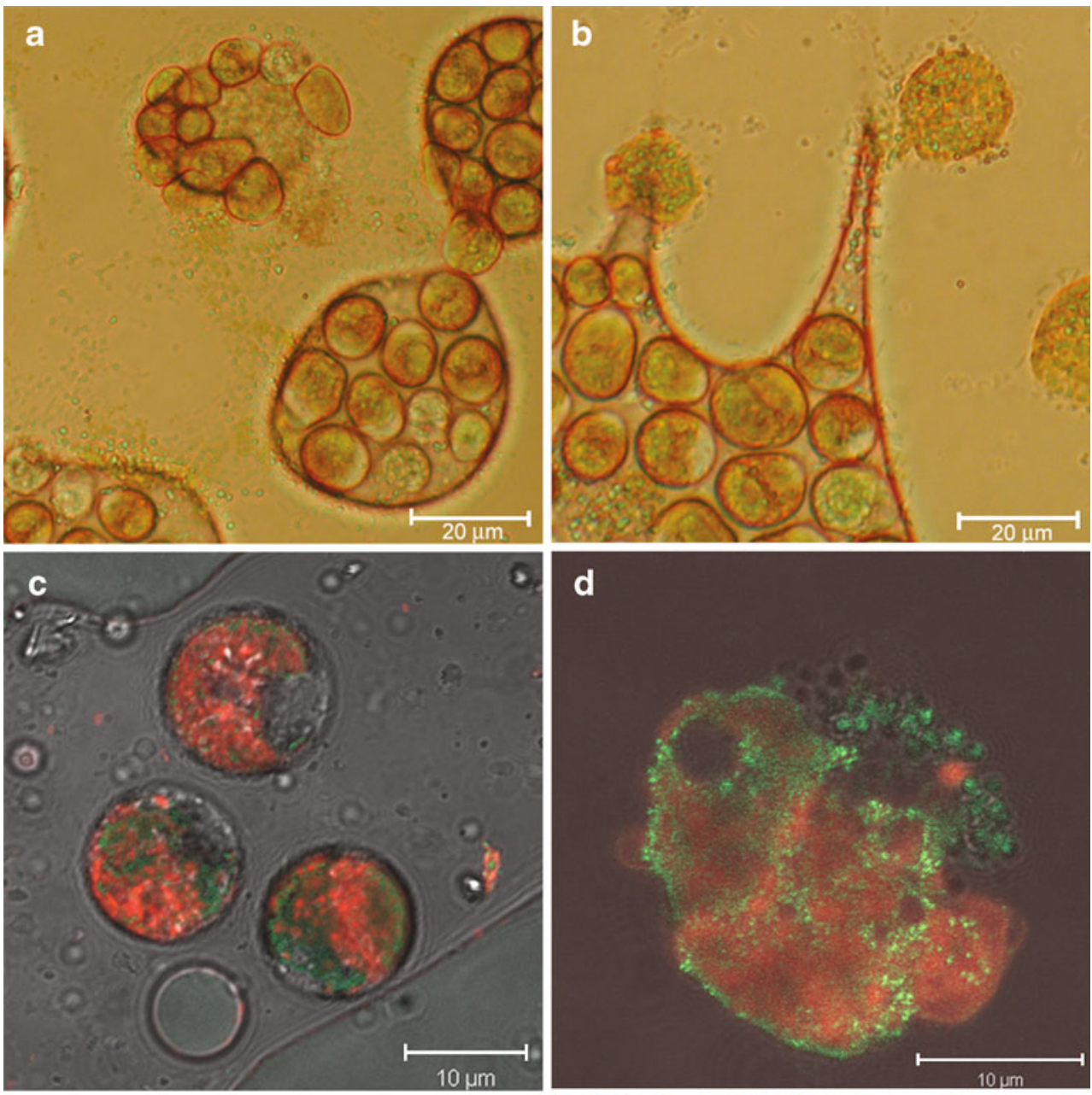

d
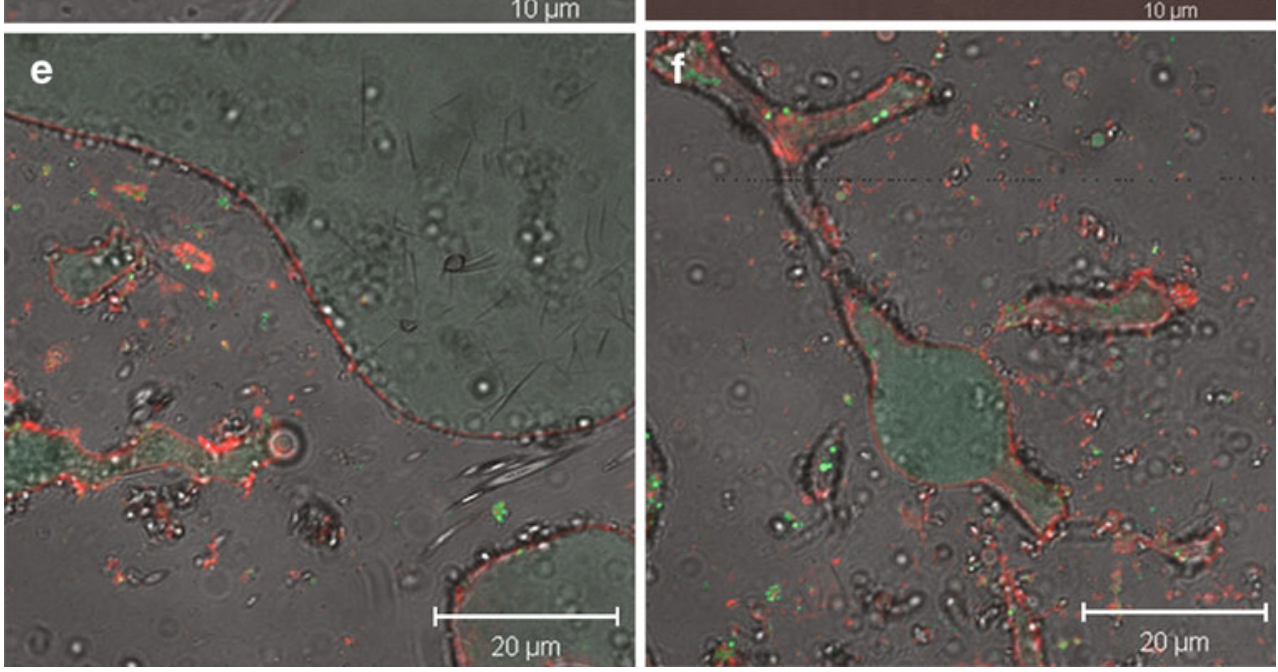
Fig. $2 \mathrm{a}$ and $\mathrm{b}$. Figure $2 \mathrm{c}$ and $\mathrm{d}$ show fluorescence microscopy pictures of surviving cells in the water phase and a cell that did not survive contact with the dodecane. The living cells were nicely round and were actively moving with their flagella, while dead cells showed a very rough surface indicating a distorted membrane. Most dead cells decomposed completely as can be seen in Fig. 2e and f. Small red and green fluorescent algal parts (red and green fluorescence are emitted by chlorophyll and carotenoid globules, respectively) remained in the water phase or at the interphase between the dodecane droplets and the water. Moreover, the colorless dodecane phase started to show green fluorescence, indicating the presence of dissolved $\beta$-carotene.

Fluorescence microscopy pictures of cells from a twophase culture mixed and kept in the dark for $48 \mathrm{~h}$ show that surviving cells did not lose a significant amount of their carotenoids as shown in Fig. 3.

The role of dodecane in the extraction process

The effect of direct dodecane-cell contact during the extraction process was examined. Dodecane was sparged through the medium with different velocities; at higher dodecane sparging rates the contact area between both phases is enlarged. Four reactor flasks were used; one reactor flask was a blank without organic phase, to determine the effect of stirring and dark incubation on cell death. One reactor flask had a stagnant layer of dodecane $(200 \mathrm{~mL})$ on top with no interphasial mixing, as a blank. And two reactor flasks were sparged with dodecane, at $300 \mathrm{mLL}^{-1} \mathrm{~min}^{-1}$ and at $400 \mathrm{mLL}^{-1} \mathrm{~min}^{-1}$.

As can be seen from Fig. 4 some cell growth still occurred during the first hours of the experiment, depicted as negative cell death in Fig. 4c. However, after these first hours growth was completely stopped and cell death could be demonstrated. At higher sparging rates, the cell- dodecane contact area is enlarged and from Fig. 4 it follows that the faster dodecane was sparged, the more cell death occurred. It is also shown that as the cell death rate increased, the rate of extraction increased as well. Clearly, there is a direct relation between death rate and extraction rate (Fig. $4 \mathrm{~b}$ and c).

Some cell death was observed in the blank experiment as well, due to stirring and prolonged incubation without light (Fig. 4a). The presence of a stagnant dodecane phase did not increase cell death in comparison to the blanks, nor did a very low sparging rate $\left(14 \mathrm{mLL}^{-1} \mathrm{~min}^{-1}\right.$, results not shown). A sparging rate of $100 \mathrm{mLL}{ }^{-1} \cdot \mathrm{min}^{-1}$ showed a slight increase in cell death but due to the inherent noise on the cell counting measurements it was not significant compared to the blanks (results not shown). The extraction of $\beta$ carotene in the reactor with a stagnant dodecane phase or the low sparging rates was likewise to cell death very low.

\section{Role of dichloromethane in extraction process}

A similar experiment as the aforementioned extraction experiment with dodecane was performed, but now with dichloromethane added to the organic phase. The experiment was performed in two subsequent runs, each with a different dichloromethane concentration $(1.2 \% v / v$ and $5.0 \% v / v)$ and starting from a new carotenoid-rich cell suspension grown in the panel photobioreactor. For every run, four reactor flasks were used: one as a blank without organic phase, and one with a stagnant layer of organic phase on top to examine the possible molecular toxic effect of the organic phase. The other two reactors were sparged with organic phase (duplicate) at $300 \mathrm{mLL}^{-1} \mathrm{~min}^{-1}$.

As can be seen in Fig. 5, the influence of dichloromethane on cell death varies with the concentration. At a concentration of $1.2 \% v / v$ no increase in cell death was observed compared to a culture without dichloromethane added to the organic phase. At a concentration of $5 \% \mathrm{v} / \mathrm{v}$
Fig. 3 CLSM pictures of $D$. salina cells from a two-phase system. The cells still had significant amounts of carotenoids after being exposed to dodecane in a mixed two-phase system for $48 \mathrm{~h}$. Red fluorescence is emitted by chlorophyll, green by the carotenoid globules
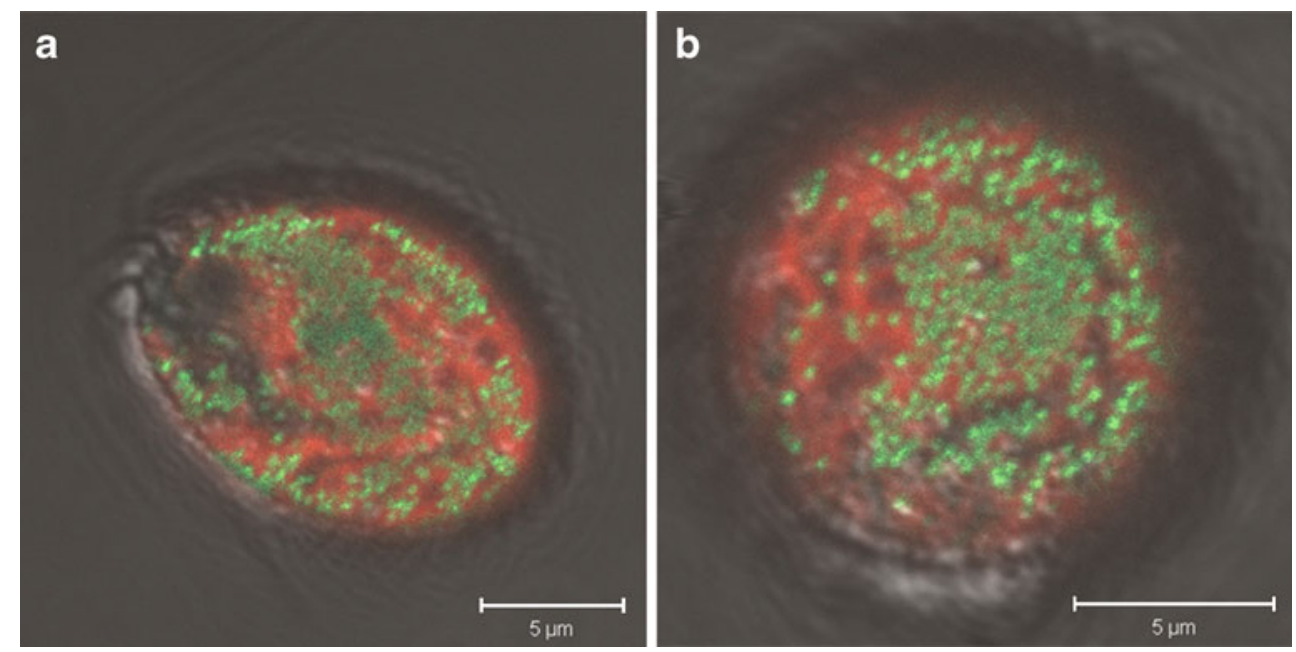

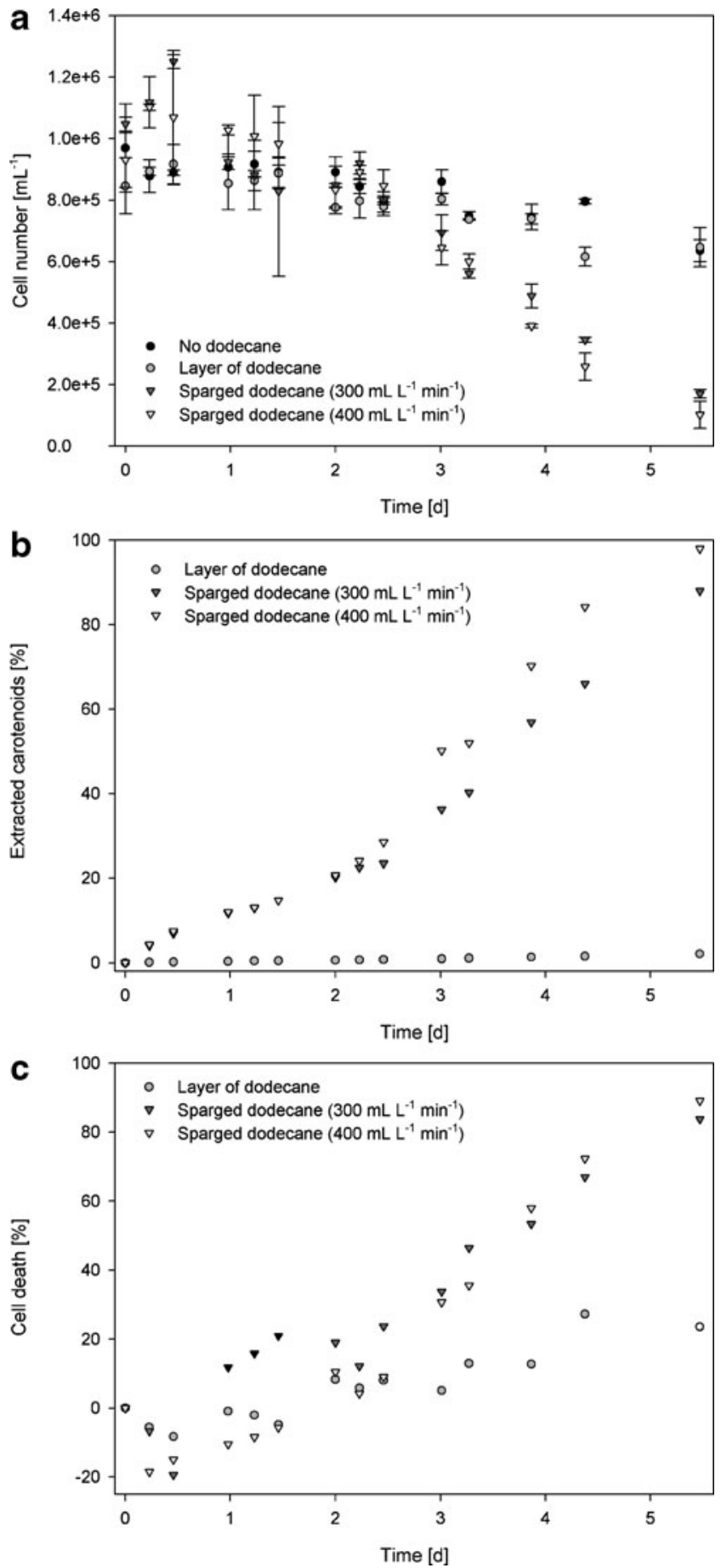

Fig. 4 Cell numbers and carotenoid extraction in two-phase (dodecane/aqueous phase) stirred reactor systems in time. One reactor without organic phase, one with stagnant layer of dodecane on top and two systems with dodecane sparged through (300 and $400 \mathrm{mLL}^{-1} \mathrm{~min}^{-1}$ ). a Cell concentration in time. Error bars standard deviation, $n=2$. b Extracted $\beta$-carotene in percentage of total $\beta$ carotene present versus time. c Cell death as \% calculated from cell number at the start of the experiment in time

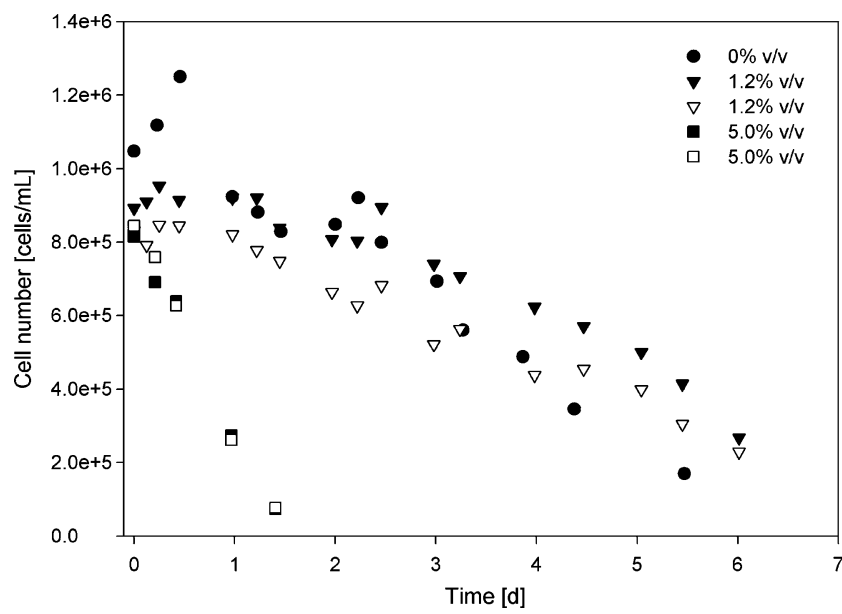

Fig. 5 Cell numbers in a two-phase system (aqueous phase/dodecane) in time. The influence of different concentrations of dichloromethane in dodecane $(0 \%, 1.2 \%, 5 \% \mathrm{v} / \mathrm{v})$ were determined. The organic phase was sparged through the medium with $300 \mathrm{mLL}^{-1} \mathrm{~min}^{-1}$

cell death occurred much faster and approximately all cells were dead after 1.5 days, whereas at a dichloromethane concentration of $0 \% v / v$ or $1.2 \% v / v$ after more than 5 days still more than $20 \%$ of the cells was alive. Also, in the reactor with only a stagnant layer of organic phase, the cell number drastically decreased when $5.0 \% v / v$ dcm was present in the organic (dodecane) phase, in comparison to $0 \% v / v$ and $1.2 \% v / v$ dichloromethane present (Fig. 6).

In Fig. $7 \mathrm{a}-\mathrm{c}$, the extraction of $\beta$-carotene in the absence and presence of dichloromethane is shown. In the first period of the experiment, the extraction goes somewhat faster than the cell death, especially in the case of $1.2 \%$ dichloromethane. Furthermore, the extraction of $\beta$-carotene by the organic phase appeared to parallel the degree of cell death.

\section{Discussion}

The milking process has shown to be a successful way of in situ extraction of carotenoids from $D$. salina, while retaining constant biomass levels (Hejazi et al. 2004a, b). However, the mechanism of extraction is unclear, as is the influence of the organic phase on the cells. The objective of this study was to show the effect of the organic phase on the cells and its influence on the extraction mechanism.

The effect of direct contact between cells and dodecane As shown microscopically, D. salina cells died and often ruptured when they were brought into direct contact with the organic phase. There are various reasons why the presence of a solvent phase can be toxic to a cell, such as nutrient extraction from the aqueous phase to the organic phase, disruption of cell membranes and limited access to nutrients due to emulsion formation or coating of the cell 


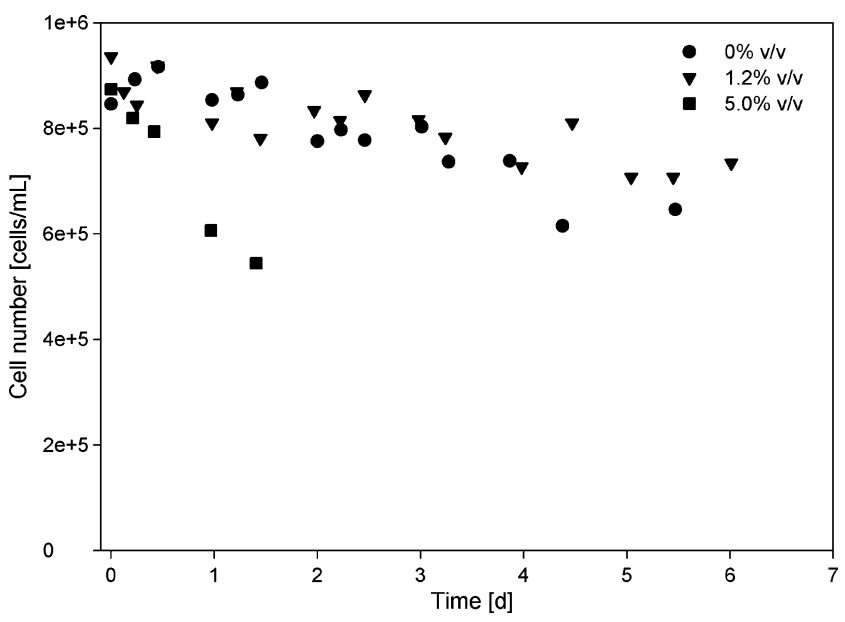

Fig. 6 Cell numbers in a two-phase system (aqueous phase/dodecane) in time. The influence of different concentrations of dichloromethane in dodecane $(0 \%, 1.2 \%, 5 \% v / v)$ were determined. The organic phase was present as a stagnant layer on top of the aqueous phase

with solvent (Bar 1987). The duration of the experiments will not have been long enough for any deprivation of nutrients to take effect. Disruption of the cellular membrane is the most obvious reason for D. salina cells to die. This effect has been mentioned before in various cases as main toxic effect upon addition of apolar solvents to various microorganisms (Bruce and Daugulis 1991; Osborne et al. 1990; Hocknull and Lilly 1987; Vermue et al. 1993).

During in situ extraction in a reactor experiment, however, the number of ruptured cells is difficult to measure. The method described by Hejazi et al. (2003) to determine the viability of the cells by means of flow cytometry could only distinguish between live and dead 'intact' cells but it could not account for ruptured cells. If the number of cells stays constant during extraction, cell death cannot be excluded as cell growth could have occurred at the same time. For that reason, we arrested cell growth by addition of hydroxyurea to the aqueous phase. By stopping cell growth, cell death can be quantified by measuring the number of intact cells during the extraction experiment. Hydroxyurea acts as DNA synthesis inhibitor. It does not prohibit cell proliferation immediately after addition. Zachleder (1994) showed that the reproductive processes that the cells had already commenced were still completed after the addition of hydroxyurea.

In our experiments, some cell growth indeed still occurred during the first hours of the experiment. However, after these first hours, growth was completely stopped and cell death could be demonstrated, confirming the microscopic observations. Moreover, an increase in the sparging rate resulted in increased cell death and increased extraction rates.

From these experiments, we can conclude that Dunaliella cells died when in direct contact with the solvent phase but remained viable in the water phase. So dodecane does exert phase toxicity but does not exert molecular
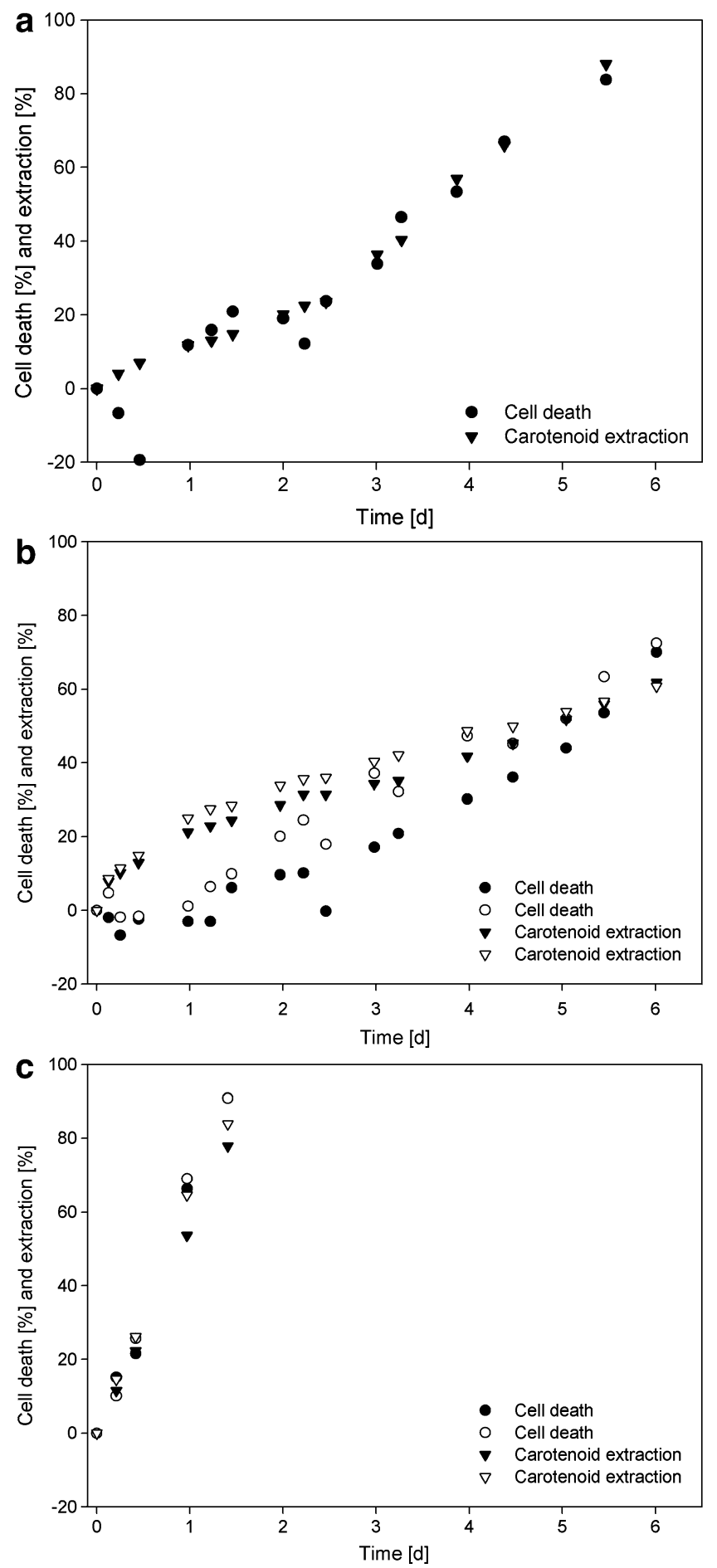

Fig. 7 Cell death and carotenoid extraction in time for the reactors sparged $\left(300 \mathrm{mLL}^{-1} \mathrm{~min}^{-1}\right)$ with organic phase with three different dichloromethane concentrations in the organic phase (dodecane): a $0 \% v / v, \mathbf{b} 1.2 \% v / v ;$ c $5.0 \% v / v$

toxicity. Thus far, phase toxicity of dodecane on Dunaliella cells was mainly determined by, e.g., oxygen evolution rate for a total culture and not for single cells with direct contact (Mojaat et al. 2008; Hejazi et al. 2002). This can be the reason why this phase toxicity was not found before. 
Role of dichloromethane in the extraction process The addition of very small amounts of dichloromethane has been suggested to improve carotenoid extraction from $D$. salina due to both a higher affinity of the extracted $\beta$-carotene with the organic phase and to the permeability effect of mixed solvents on the cell membrane (Mojaat et al. 2008). As we showed before, the extraction of $\beta$-carotene was found to be correlated to cell death. The question remains whether the improved extraction reported with dichloromethane addition could also be a result of increased cell death.

An organic solvent can both exert molecular toxicity, when the solvent is present in levels below saturation, and physical toxicity when there is enough solvent present to form a separate phase (Bar 1987). As discussed before, phase contact between cells and dodecane is toxic to the cells. However, dodecane does not show molecular toxicity. Dichloromethane is toxic to cells already on a molecular level. Osborne et al. (1990) found that total loss of activity of cells corresponded to a constant solvent concentration in the membrane, irrespective of the solvent type used, the socalled critical membrane concentration.

As long as the critical aqueous concentration of dichloromethane, which is the concentration in the water phase corresponding to the critical membrane concentration, is not reached, dichloromethane should not be toxic to a cell. Therefore, we set our aqueous dichloromethane concentrations to be well below the critical aqueous concentration, namely $16(1.2 \% v / v)$ and $66 \mathrm{mM}(5.0 \% v / v)$ with corresponding membrane concentrations of 35 and $148 \mathrm{mM}$, respectively (see appendix for calculations). Mojaat et al. (2008) determined the critical membrane concentration of dichloromethane to be $271 \mathrm{mM}$.

It was shown that cell death increased steeply in case of $5.0 \%$ dichloromethane, compared to $1.2 \%$ dichloromethane in the organic phase. Apparently at around 5.0\%, dichloromethane does show molecular toxicity. This was also observed in the reactor where only a stagnant layer of organic phase was present. A reason for this discrepancy in toxicity compared to the value for the critical membrane concentration obtained by Mojaat et al. (2008) could be the type of measurement determining viability of the culture, namely oxygen evolution for a short period of time versus cell counting.

During the first days of the extraction experiment of $1.2 \%$ dichloromethane, the extraction rate was slightly higher than the cell death rate. This can be either due to the increased distribution coefficient of $\beta$-carotene for the solvent mixture compared to pure dodecane or just to more dead cell material already present in the cell suspension at the start of the experiment. However, primarily, the extraction rate of $\beta$-carotene in presence of dichloromethane ran parallel to cell death. We conclude therefore that cell death is the most important factor determining the $\beta$-carotene extraction rate.
Milking In the above experiments, extraction of $\beta$-carotene was mainly attributed to cell death. Cells that were extracted for $48 \mathrm{~h}$ in a two-phase system with dodecane as organic phase still showed significant amount of carotenoids. However, no evidence was found that living cells cannot lose at least a small part of their carotenoids.

The fact that cells die during the extraction process seems contradictory to the milking process with constant biomass levels reported earlier (Hejazi et al. 2004a; Leon et al. 2003). However, the results found in our study do not have to conflict with those results. If cell growth and cell death cancel each other out, a net constant cell level remains. These antagonistic processes of simultaneous cell growth and destruction have been previously described by Bar (1988) in a dodecanol two-phase system for the yeast Saccharomyces cerevisiae. This would also explain the frequent observed biocompatibility of dodecane for $D$. salina cells; single cells die because of direct phase contact, but the culture as a whole remains viable.

We found that it took approximately 3 days to reduce the cell number by half when pure dodecane was used as an organic phase. In order to keep biomass levels constant, the cell division rate should equal this death rate. Under stress conditions cell growth is limited but a doubling rate of a few days is certainly possible as observed by Ben-Amotz (1995) and Lamers et al. (2010).

In conclusion, contact between cells and the waterdodecane interphase resulted in cell death, as was observed microscopically. In two-phase systems, the cell death rate increased with increasing sparging rates of the organic phase. Furthermore, it was shown that small amounts of dichloromethane $(\leq 1.2 \% v / v$ in organic phase, dodecane) do not result in increased cell death when compared to absence of dichloromethane. However, when the dichloromethane concentration is increased cell death increases as well. The amount of $\beta$-carotene extraction was in all cases proportional to the cell death rate. Therefore, we conclude that extraction is mainly based on cell death, and the cell death rate is the most important and limiting step in extraction.

Acknowledgments The authors would like to thank André van Lammeren and Norbert de Ruijter of Laboratory of Plant Cell Biology, Wageningen University for stimulating discussions and great help with the microscopy experiments. Furthermore, they would like to thank Arjen Rinzema of Bioprocess Engineering, Wageningen University for his help with the calculations of the critical membrane concentrations. This research was financially supported by the technology foundation STW (www.stw.nl; project WLM.6622), which is part of the Netherlands Organisation for Scientific Research (www.nwo.nl).

Open Access This article is distributed under the terms of the Creative Commons Attribution Noncommercial License which permits any noncommercial use, distribution, and reproduction in any medium, provided the original author(s) and source are credited. 


\section{Appendix I: calculation dichloromethane concentration in cell membrane}

Determination of the partition coefficient of dichloromethane in a dodecane/water mixture $\left(P_{\mathrm{dcm} \_\mathrm{d} / \mathrm{w}}\right)$ with ProSimPlus 3 (ProSim SA, France), based on UNIFAC data.

In a system with $500 \mathrm{~mL}$ water, $197.57 \mathrm{~mL}$ dodecane and $2.43 \mathrm{~mL}$ dichloromethane $\left(1.2 \% v_{\mathrm{dcm}} v_{\text {org.fase }}{ }^{-1}\right)$, the dichloromethane partitions between the dodecane phase and the water phase. We calculated the dichloromethane concentration in the water phase $\left(C_{\mathrm{dcm} \text { w }}\right)$ to be $1.67 \times$ $10^{-2} \mathrm{~mol} \mathrm{~L}^{-1}$ and the dichloromethane concentration in the dodecane $\left(C_{\mathrm{dcm} \_\mathrm{d}}\right)$ to be $1.58 \times 10^{-1} \mathrm{~mol} \mathrm{~L}^{-1}$.

In the system with $500 \mathrm{~mL}$ water, $190 \mathrm{~mL}$ dodecane and $10 \mathrm{~mL}$ dichloromethane $\left(5.0 \% v_{\mathrm{dcm}} v_{\text {org.fase }}{ }^{-1}\right)$, we calculated the dichloromethane concentration in the water phase $\left(C_{\mathrm{dcm} \_\mathrm{w}}\right)$ to be $6.12 \times 10^{-2} \mathrm{~mol} \mathrm{~L}^{-1}$ and the dichloromethane concentration in the dodecane $\left(C_{\mathrm{dcm} \_\mathrm{d}}\right)$ to be $6.32 \times$ $10^{-1} \mathrm{~mol} \mathrm{~L}^{-1}$.

This gave a partition coefficient of dichloromethane in a dodecane/water mixture $\left(P_{\mathrm{dcm} \_\mathrm{d} / \mathrm{w}}\right)$ of:

$P_{d c m \_d / w}=\frac{C_{d c m \_d}}{C_{d c m \_w}}=9.9$ (averaged for both situations)

Calculation volume of cell membrane present in water phase:Assumptions:

- Number of cells present $\left(\#_{\text {cells }}\right): 1.0 \times 10^{9}$ cells L ${ }^{-1}$

- Thickness cell membrane (h): $1.0 \times 10^{-8} \mathrm{~m}$

- Diameter of cells (d): $1.0 \times 10^{-5} \mathrm{~m}$

Volume cell membrane $\left(V_{\text {mem }}\right): \pi \times d^{2} \times h=3.14 \times$ $10^{-18} \mathrm{~m}^{3} \times \mathrm{cell}^{-1}$

Total volume membrane: $\#_{\text {cells }} \times V_{\text {mem }}=3.14 \times 10^{-6} \mathrm{~L}_{\mathrm{mem}} \times$ $\mathrm{L}_{\mathrm{w}}{ }^{-1}$

Table 1 Data for calculation of dichloromethane concentration in aqueous phase and membrane

\begin{tabular}{lll}
\hline Data & $1.2 \% \mathrm{v} / v$ & $5.0 \% \mathrm{v} / v$ \\
\hline$M_{\mathrm{DCM}}[\mathrm{mol}]$ & 0.038 & 0.156 \\
$v_{\mathrm{w}}[\mathrm{L}]$ & 0.500 & 0.500 \\
$v_{\mathrm{d}}[\mathrm{L}]$ & 0.197 & 0.190 \\
$v_{\text {mem }}[\mathrm{L}]$ & $0.5 \times 3.14 \cdot 10^{-6 \mathrm{a}}=$ & $0.5 \times 3.14 \times 10^{-6 \mathrm{a}}=$ \\
& $1.57 \times 10^{-6}$ & $1.57 \times 10^{-6}$ \\
$P_{\mathrm{dcm} \_\mathrm{d} / \mathrm{w}}[-]$ & $9.9^{\mathrm{a}}$ & $9.9^{\mathrm{a}}$ \\
$P_{\mathrm{dcm} \_ \text {mem/ }}$ & $2.26^{\mathrm{b}}$ & $2.26^{\mathrm{b}}$ \\
${ }_{\mathrm{w}}[-]$ & & \\
\hline
\end{tabular}

$M_{\mathrm{dcm}}$ mass dichloromethane, $v_{\mathrm{w}}$ volume water, $v_{\mathrm{d}}$ volume dodecane, $v_{\text {mem }}$ volume cell membrane and $P_{\mathrm{dcm} \_\mathrm{mem} / \mathrm{w}}$ partition coefficient of dichloromethane in cell membrane/water

${ }^{\mathrm{a}}$ See calculation above

${ }^{\mathrm{b}}$ Data from Mojaat et al. (2008)
Table 2 Dichloromethane concentrations in aqueous phase and in cell membrane

\begin{tabular}{lcc}
\hline Data & $1.2 \% v / v$ & $5.0 \% v / v$ \\
\hline$C_{\mathrm{dcm} \_\mathrm{w}}[\mathrm{mM}]$ & 16 & 66 \\
$C_{\mathrm{dcm} \_ \text {mem }}[\mathrm{mM}]$ & 35 & 148 \\
\hline
\end{tabular}

Calculation of the dichloromethane concentration in the cell membrane $\left(C_{\mathrm{dcm} \_ \text {mem }}\right)$ in a system with $500 \mathrm{~mL}$ water, $197.57 \mathrm{~mL}$ dodecane, $2.43 \mathrm{~mL}$ dichloromethane $\left(1.2 \% v_{\mathrm{dcm}}\right.$ $\left.v_{\text {org.fase }}{ }^{-1}\right)$ and $1.0 \times 10^{9}$ cells $\cdot \mathrm{L}^{-1}$ present, the dichloromethane partitions between the water phase, the dodecane, and the cell membrane (Table 1).

Equations:

$$
\begin{aligned}
& M_{d c m}=V_{w} \times C_{d c m \_w}+V_{d} \times C_{d c m \_d}+V_{m e m} \times C_{d c m \_m e m} \\
& C_{d c m \_d}=P_{d c m \_d / w} \times C_{d c m \_w} \\
& C_{d c m \_m e m}=P_{d c m \_m e m / w} \times C_{d c m \_w}
\end{aligned}
$$

With three equations and three unknowns $\left(C_{\mathrm{dcm} \_ \text {w }}, C_{\mathrm{dcm} \_\mathrm{d}}\right.$, $\left.C_{\mathrm{dcm} \text { mem }}\right)$ we can calculate the dichloromethane concentration in the aqueous phase and in the cell membrane (Table 2).

\section{References}

Bar R (1987) Phase toxicity in a water-solvent two-liquid phase microbial system. In: Laane C, Tramper J, Lilly MD (eds) Biocatalysis in organic media: Proceedings of an international symposium. Elsevier, Amsterdam, pp 147-156

Bar R (1988) Effect of interphase mixing on a water-organic solvent two-liquid phase microbial system: ethanol fermentation. J Chem Tech Biotechnol 43:49-62

Ben-Amotz A (1995) New mode of Dunaliella biotechnology: two-phase growth for $\beta$-carotene production. J Appl Phycol 7:65-68

Ben-Amotz A, Katz A, Avron M (1982) Accumulation of $\beta$-carotene in halotolerant algae: purification and characterization of $\beta$ carotene-rich globules from Dunaliella bardawil (Chlorophyceae). J Phycol 18:529-537

Borowitzka MA (1999) Commercial production of microalgae: ponds, tanks, tubes and fermenters. J Biotechnol 70:313-321

Bruce LJ, Daugulis AJ (1991) Solvent selection strategies for extractive biocatalysis. Biotechnol Prog 7:116-124

Evans PJ, Wang HY (1988) Responce of Clostridium acetobutylicum to the presence of mixed extractants. Appl Biochem Biotechnol $16: 113-122$

Hejazi MA, de Lamarliere C, Rocha JMS, Vermuë M, Tramper J, Wijffels RH (2002) Selective extraction of carotenoids from the microalga Dunaliella salina with retention of viability. Biotechnol Bioeng 79:29-36

Hejazi MA, Andrysiewicz E, Tramper J, Wijffels RH (2003) Effect on mixing rate on $\beta$-carotene production and extraction from Dunaliella salina in two-phase bioreactors. Biotechnol Bioeng 84:591-596 
Hejazi MA, Holwerda E, Wijffels RH (2004a) Milking microalgae Dunaliella salina for $\beta$-carotene production in two-phase bioreactors. Biotech Bioeng 85:475-481

Hejazi MA, Kleinegris D, Wijffels RH (2004b) Mechanism of extraction of $\beta$-carotene from microalgae Dunaliella salina in two-phase bioreactors. Biotech Bioeng 88:593-600

Hocknull MD, Lilly MD (1987) The $\Delta^{1}$-hydrogenation of hydrocortisone by Arthrobacter simplex in organic-aqueous two-liquid phase environments. In: Laane C, Tramper J, Lilly MD (eds) Biocatalysis in organic media: Proceedings of an international symposium. Elsevier, Amsterdam, pp 393-398

Kleinegris DMM, van Es MA, Janssen M, Brandenburg WA, Wijffels RH (2010a) Carotenoid fluorescence in Dunaliella salina. J Appl Phycol 22:645-649

Kleinegris DMM, Janssen M, Brandenburg WA, Wijffels RH (2010b) The selectivity of milking of Dunaliella salina. Mar Biotech 12:14-23

Lamers PP, Laak CCW van der, Kaasenbrood PS, Lorier J, Janssen M, de Vos RCH, Bino RJ, Wijffels RH (2010) Carotenoid and fatty acid metabolism in light-stressed Dunaliella salina. Biotechnol Bioeng 106:638-648

Leon R, Martín M, Vigara J, Vilchez C, Vega JM (2003) Microalgae mediated photoproduction of $\beta$-carotene in aqueous-organic two phase systems. Biomol Eng 20:177-182

Mojaat M, Foucault A, Pruvost J, Legrand J (2008) Optimal selection of organic solvents for biocompatible extraction of $\beta$-carotene from Dunaliella salina. J Biotechnol 133:43-441

Osborne SJ, Leaver J, Turner MK, Dunnill P (1990) Correlation of biocatalytic activity in an organic-aqueous two-liquid phase system with solvent concentration in the membrane. Enzyme Microb Technol 12:281-291

Vermue M, Sikkema J, Verheul A, Bakker R, Tramper J (1993) Toxicity of homologous series of organic solvents for the gram-positive bacteria Arthrobacter and Nocardia sp. and the gram-negative bacteria Acinetobacter and Pseudomonas sp. Biotech Bioeng 42:747-758

Zachleder V (1994) The effect of hydroxyurea and fluorodeoxyuridine on cell cycle events in the chlorococcal alga Scenedesmus quadricauda (Chlorophyta). J Phycol 30:274-279 